\title{
"Socio-Epidemiological Co-Relates Of Age At Marriage: A Comparative Study From West Bengal".
}

\author{
*Dr. Anima Haldar, **Dr. Ramaprasad Roy, ${ }^{* * *}$ Dr. Sarmila Mallik,**Dr. \\ Subhrajyoti Naskar, $* * * *$ Dr. Baijayanti Baur, $* * * * *$ Dr. Tutul Chatterjee, \\ * MBBS, DMCW, MD (Community Medicine),Faculty Members of Department of Community Medicine, \\ Midnapur Medical Collage, Paschim Midnapur \\ ** MBBS,MD, Faculty member of Department of Community Medicine, Malda Medical College, Malda. \\ *** MBBS, DCH, MD (Community Medicine), Faculty Member of Department of Community Medicine, \\ Calcutta National Medical College, Kolkata \\ **** MD (Community Medicine), Faculty member of Department of Community Medicine, Medical College, \\ Kolkata. \\ ***** MD (Community Medicine), Faculty member of Department of Community Medicine, IDBG Hospital, \\ Kolkata.
}

\begin{abstract}
Background: A substantial proportion of marriages continue to take place when the girl is below18 years of age in different states of India especially in rural area. Different socio-epidemiological factors are influencing the age at marriage of women. So this study was conducted to assess the current status of early marriage and teenage pregnancy and also to compare influence of socio-epidemiological co-relates over such situation in Howrah and Paschim Midnapur districts of West Bengal.

Materials\& Methods: A total of 4000 eligible couples were selected by stratified multistage random sampling from two districts of West Bengal. Data were collected by interview technique from the female member of the eligible couples by house to house survey and was analyzed both manually and by computer using EPIINFO.

Results: In both districts more than half of the women were married below 18 years. But it was significantly higher in Paschim Midnapur (rural-58.8\%, urban-61.8\%) than Howrah (rural-54.5\%, urban-56.8\%).The intra district rural-urban variation was minimum. In both districts marriage below 18 years was higher among Muslims and among women with lower educational and social status. The differences were statistically significant. The range of teenage pregnancy varied from $60 \%$ to68.8\% among other religion to Muslim in Howrah district where as it was varied from $50 \%$ to $71.1 \%$ in Paschim Midnapur.
\end{abstract}

\section{Introduction:}

Marriage is not only universal in India but it takes place at an early age. Society expected the girl to be married early because the correct ideal of chastity required that "the maiden should not feel love for a man other than the one to whom she might eventually get married. ${ }^{1}$ Since virginity was a badge of respectability, "marriage would be desired before any scope for suspicion regarding the virginity of a girl presented itself. ${ }^{2}$ Efforts have been made in modern times to raise the age at marriage by legislation. In 1929, the Child Marriage Restraint Act was passed. The Act prohibited "child" marriages, the term child being defined as a male under eighteen or a female below fourteen years of age. ${ }^{3}$ Nevertheless, it is quite clears that fertility in India would increase because of the lengthening of the span of men and women who continue to remain in fertile union. The Child Marriage Restraint Act of 1978 raise the legal age at marriage from 15 to 18 years for girls, and from 18 to 21 years for boys. But a substantial proportion of marriages continue to take place when the girl is around 15 years of age in different states of India especially in rural area. ${ }^{4,5}$

The median age at first marriage is 17 years among women aged 20-49 and 24years among men aged 25-49. On average, men get married almost 7 years later than women. More than one-half $(54 \%)$ of women age 20-24 years got married before the legal minimum age of 18 and 27 percent of men aged 25-29 years got married before the legal minimum age of $21 .{ }^{6}$ The higher literacy \& educational level of women \& rise in age at marriage played an important role in the improved health care of children with in the family. ${ }^{7}$ Higher age at marriage for girls \& boys along with higher level of contraception functioned at intermediate or proximate variables which led to lower fertility in Kerala. ${ }^{8}$ To bring down maternal and child mortality, early marriage and occurrence of teenage pregnancy should be reduced throughout India.

With the above perspectives the present study was carried out to assess the current status of early marriage and teenage pregnancy and also to compare the socio-epidemiological co-relates influencing such situation in two districts of West Bengal. 


\section{Materials And Methods:}

Community based cross-sectional observational study was carried out in two districts of West Bengal during the month of March-- October 2009.Villages and Municipality wards of Howrah district \& West Midnapur district were selected randomly for study purpose.

Sampling technique: Stratified Multi stage random sampling

Out of total 19 districts in West Bengal, 2 districts were selected randomly for the study purpose.

Out of total blocks in each district, 3 blocks had been selected randomly.

From each rural block 2 sub-centers and from each sub centre area, 2 villages had been selected randomly.

Out of total municipalities of each district, 2 municipality areas were selected randomly.

From each municipality, 2 wards had been selected randomly.

Total 12 villages ( 4 villages from each block) and 4 wards ( 2 wards from one municipality) had been chosen for study purpose.

So total 16 areas had been selected throughout one district ( 3 blocks X 4 villages +2 wards $\mathrm{X} 2$ municipality $=$ 16).

Sample size: Based on present couple protection rate of West Bengal (49.5\%), the minimum Sample size comes to be 1600 (approx) considering allowable error $5 \%$.

Here, $\mathrm{P}=49.5, \mathrm{Q}=50.5, \mathrm{~L}=2.5$ (allowable error $5 \%$ ).

So, $n=4 \mathrm{PQ} / \mathrm{L}^{2}=1600$ (approx) for each district. So for two districts 4000 eligible couples were considered (2000 eligible couples from each district) as adequate sample size.

Thus a total of 4000 eligible couples were interviewed from two districts by house to house survey (As urban and rural population are in the ratio of 1:3, So total 16 clusters selected for each district were also distributed in the same ratio, i.e. 4 urban wards from municipality areas and 12 villages from blocks).

From each selected 16 areas, 125 eligible couples to be covered to get 2,000 eligible couples from each district. Data collection technique:

Data collected by interview technique from the respondents (Female member of E.C) through predesigned and pretested schedule by House to House survey. Faculty members of the Department of Community medicine of Calcutta National Medical College, also faculties from other Medical Colleges and Interns participated in the survey.

Variables like Socio-Economic status of the families was determined from per capita monthly income. ${ }^{9}$ Supervision was done in the field by the investigators and other senior Professors of Calcutta National Medical College. Finally data for all parameters were analyzed both manually and by computer using EPI-INFO.

\section{Results:}

The study was conducted among 4000 currently married women in two districts of West Bengal, India. It was revealed from Table no- 1 that more than half of the women in both the districts were married below 18 years of age, but it was quite higher (59.5\%) in Paschim Midnapur than Howrah district where it was $55.1 \%$ and the difference was statistically significant $(\mathrm{p}<0.05)$.

Table-II showed that age at marriage below18 years among Muslims was quite higher than Hindus \& others in both the districts. Out of total Muslim respondents, $61.8 \%$ married below 18 years of age in Howrah district whereas it was quite higher (66.3\%) in Paschim Midnapur district. Religionwise differences were statistically significant in both districts ( $\mathrm{p}=0.0000, \mathrm{p}=0.01$ respectively).

Table-III also showed that there was variation of age at marriage of currently married women according to their social class in both the districts. In Howrah district, age at marriage below 18 years was 64.2\%, 54.2\%, 36.6\%, $39.4 \%, 21.2 \%$ among those who belonged to very poor ( BPL), poor, lower, upper middle, upper high \& high socio-economic-status group respectively. In Paschim Midnapur district it was 63.5\%, 55\%, 51.1\%, 52.4\%, $36.4 \%$ among those who belonged to very poor (BPL), poor, lower, upper middle, upper high \& high socioeconomic-status group respectively. Statistically significant difference was observed in both districts.

It was revealed from Fig-I that variation of age at marriage below 18 years of the study population according to their place of residence. Age at marriage below 18 years was higher in both rural (58.8\%) and urban (61.8\%) area of Paschim Midnapur than Howrah district where it was 54.5\% and 56.8\% respectively. 
"Socio-epidemiological co-relates of age at marriage: a comparative study from west Bengal".

Table-IV (Fig-II) also showed that age at marriage below 18 years was inversely proportional to the literacy status of the currently married women in both the districts. In Howrah district age at marriage below18 years was73.1\%,65.1\%,56.6\%,42.3\% among those who belonged to illiterate, just-literate, primary educated, secondary\& above groups and the difference was statistically significant $(\mathrm{p}=0.00000)$. In Paschim Midnapur district the age at marriage below 18 years was $91.5 \%, 75.8 \%, 35.5 \%, 21.1 \%$ among illiterate, just literate, primary educated, secondary \& above groups respectively and the difference was statistically significant $(\mathrm{p}=.0000)$.

It was depicted from Fig-III that occurrence of pregnancy below 20 years of age by religion in two districts of West Bengal. In both the districts the teenage pregnancy was highest among the Muslims followed by Hindu, then other religious groups. The range varies from $60 \%$ to $68.8 \%$ among different religious groups in Howrah district whereas it was varied from 50\% to $71.8 \%$ in Paschim Midnapur district.

\section{Discussion:}

The present study clearly indicated that the socio - epidemiological factors like place of residence, literacy status, social class, religion etc were influencing age at marriage among the study population in both the districts of West Bengal.

The present study revealed that more than half of the women were married before the legal age at marriage i.e. 18 years in both the districts-Paschim Midnapur (59.5\%) and Howrah (55.1\%). National Family Health Survey -3 (2005-06) found that 44.5\% of women aged 20-24 years were married by the age of $18 .{ }^{6}$

The current study found that Muslim women were married earlier as compared to Hindu and other women (Table II). It was found that $61.8 \%$ and $66.3 \%$ of Muslim women were married below 18 years of age in Howrah and Paschim Midnapur districts respectively. National Family Health Survey -I also reported that Muslim women had relatively low age at marriage. ${ }^{7}$ Similar observation was made by Carter et al who reported that religion had a significant and direct influence on age at marriage.$^{10}$ The findings of the present study also showed a positive relationship of women's age at marriage with their educational level in the both districts. This findings corroborated with the findings of Sadasivan who observed that as the educational level rises, age at marriage correspondingly goes up and consequently the duration of married life is shortened. ${ }^{8}$ According to Dixon higher education for women can reduce fertility in at least 3 ways, one of which is by delaying marriage. ${ }^{11}$ Median age at marriage increased substantially with women's educational attainment according to NFHS-I. ${ }^{12}$ Sharma et al reported that one of the reasons of reduced fertility with higher literacy was that improvement in educational level delayed the age at marriage of girls. ${ }^{13}$

The present study revealed that age at marriage of women was influenced by their social class in both Howrah and Paschim Midnapur districts. The age at marriage below 18 years was indirectly proportional with social class. Statistically significant difference was observed in both districts. Carter et al also observed that women from lower socio-economic class were married early. ${ }^{10}$

The present study also indicated intra-district rural-urban variation of age at marriage below 18 years. Teenage marriage was higher in both urban (61.8\%) and rural (58.8\%) areas of Paschim Midnapur as compared to urban $(56.8 \%)$ and rural (54.5\%) areas of Howrah district. Earlier study also showed variation among different rural communities. ${ }^{14}$

The present study also observed that higher proportion of Muslim women had their first child birth earlier i.e. below 20 years as compared to Hindu and other religious group of women in both Howrah and Paschim Midnapur districts (Fig3).The relationship of age at first child birth and religion was also observed by NFHS- 1(1992) which found that in West Bengal Muslim women begin childbearing earlier than Hindus. ${ }^{12}$ According to NFHS-3, among young women (15-19 yrs) in West Bengal one quarter have already begun child bearing, much higher than national average $(16 \%)$ and also higher than all other Indian states except Jharkhand. ${ }^{6}$ NFHS--III also revealed that at age 15 years, $7 \%$ of women in West Bengal are already mothers or pregnant with their first child, among women age 19, this proportion increases to almost half (49\%). Young women in rural areas are almost three times as likely to be mothers or pregnant, as young women in urban areas $(30 \%$ and $11 \%$ respectively). ${ }^{6}$ The findings of the present study regarding age at first child birth did not corroborated with the findings of NFHS-3, in present study minimum rural-urban variation of teenage marriage $\&$ pregnancy.

\section{Conclusion \& Recommendation:}

It can be concluded from the present study that socio epidemiological factors has got direct influence on age at marriage irrespective of the place of residence. So awareness generation programe should be organized in the community through Sustained behavior change communication strategy to increase the age of marriage of girls to bring down fertility and maternal modality throughout the state. 
"Socio-epidemiological co-relates of age at marriage: a comparative study from west Bengal".

\section{References:}

[1]. Ketkar, S. V. History of Caste in India. Araoti, India, 1909.

[2]. Kapadia, K.M. Marriage and Family in India. Oxford University Press.

[3]. T.J. Samuel, Social Factors Affecting Fertility in India, The Eugenics Review, 1965, 57, 1.

[4]. Agarwala, S. N. India's Population Problems, $2^{\text {nd }}$ Ed, Tata Mc Graw Hill. 1977.

[5]. Sadashiviah, K.et al. Journal of Family Welfare, 1981, 27(3); 39.

[6]. NFHS-3, India 2005-2006,International Institute of Population Sciences,Mumbai,India. MEASURE

[7]. Bhat -PNM, Rajan SI. Demographic transition in Kerala re-visited. Econ Pol weekly 1990,25;957-80.

[8]. Sadasivan Nair .P. Understanding below replacement Fertility in Kerala. J.helth popul. Nutr 2010 ,28 (4). $405-412$.

[9]. A K Agarwal. Social Classification. The need to update in the present scenario, IJCM , 2008, 33(1), 50-51

[10]. Carter H \& Glick P .Marriage and the family .Cambridge Mars: Harvard university Press.1970. Cited in; Pillai V.K. Predicting age at first marriage; A review of recent models. J. family Welfare, 1985.32(1):24-25

[11]. Dixon R.B.Education \& Employment-keys to smaller families. Journal of Family Welfare.1975.

[12]. 12(2):22-23

[13]. N.F.H.S-I.IPPS.West Bengal 1992.Bombay 1995:70-101

[14]. Sharma A.K, Mishra B.D. Fertility differentials in India- an analysis of census fertility data. Journal of Family Welfare. 1975, 12 (2): 22-23

[15]. George M. Fertility differentials in a rural community.JFW 1976,22(4):3-7

Table I:

Age at marriage of currently married women in two districts of West Bengal.

\begin{tabular}{|l|l|l|l|l|l|}
\hline \multirow{2}{*}{ Age in years } & Howrah & \multicolumn{2}{l|}{ Paschim Medinipur } & $\begin{array}{l}\text { Test of significance } \\
\text { P value }\end{array}$ \\
\cline { 2 - 5 } & No & $\%$ & No & $\%$ & $\mathrm{x}^{2}=8.095$ \\
$\mathrm{p}=0.0044$ \\
\hline$<18$ years & 1102 & 55.1 & 1191 & 59.5 & \\
\hline$\geq 18$ years & 898 & 44.9 & 809 & 40.5 & \\
\hline Total & 2000 & 100 & 2000 & 100 & \\
\hline
\end{tabular}

Table II:

Marriage < 18 years of age by religion in two districts of West Bengal

\begin{tabular}{|c|c|c|c|c|c|}
\hline \multirow[t]{3}{*}{ District } & \multicolumn{4}{|c|}{ Age at marriage } & \multirow{3}{*}{$\begin{array}{l}\text { Test of significance } \\
\mathrm{P} \text { value }\end{array}$} \\
\hline & \multicolumn{2}{|l|}{$<18$} & \multicolumn{2}{|c|}{$>18$} & \\
\hline & No & $\%$ & No & $\%$ & \\
\hline Howrah & & & & & \multirow{10}{*}{$\begin{array}{l}x^{2}=17.4 \\
p=<0.0001\end{array}$} \\
\hline Hindu $(\mathrm{n}=1336)$ & 693 & 51.9 & 643 & 48.1 & \\
\hline Muslim $(n=659)$ & 407 & 61.8 & 252 & 38.2 & \\
\hline Others $(n=5)$ & 2 & 40 & 3 & 60 & \\
\hline Total $(n=2000)$ & 1102 & 55.1 & 898 & 44.9 & \\
\hline Paschim Medinipur & & & & & \\
\hline Hindu $(n=1740)$ & 1019 & 58.6 & 721 & 41.4 & \\
\hline Muslim $(n=252)$ & 167 & 66.3 & 85 & 33.7 & \\
\hline Others $(\mathrm{n}=8)$ & 5 & 62.5 & 3 & 37.5 & \\
\hline Total $(n=2000)$ & 1191 & 59.5 & 809 & 40.5 & \\
\hline
\end{tabular}

Table III:

Age at marriage in relation to their social class in two districts of West Bengal

\begin{tabular}{|c|c|c|c|c|c|}
\hline \multirow[t]{3}{*}{ District } & \multicolumn{4}{|c|}{ Age at marriage } & \multirow{3}{*}{$\begin{array}{l}\text { Test of significance } \\
\mathrm{P} \text { value }\end{array}$} \\
\hline & \multicolumn{2}{|l|}{$<18$} & \multicolumn{2}{|l|}{$>18$} & \\
\hline & No & $\%$ & No & $\%$ & \\
\hline Howrah & & & & & \multirow{13}{*}{$\begin{array}{l}x^{2}=67.7 \\
p=<0.0001\end{array}$} \\
\hline Upper High \& High $(n=33)$ & 7 & 21.2 & 26 & 78.8 & \\
\hline Upper middle $(\mathrm{n}=33)$ & 13 & 39.4 & 20 & 60.6 & \\
\hline Lower $(n=191)$ & 70 & 36.6 & 121 & 63.4 & \\
\hline Poor $(n=1070)$ & 580 & 54.2 & 490 & 45.8 & \\
\hline $\operatorname{BPL}(n=673)$ & 432 & 64.2 & 241 & 35.8 & \\
\hline Total $(n=2000)$ & 1102 & 55.1 & 898 & 44.9 & \\
\hline Paschim Medinipur & & & & & \\
\hline Upper High \& High $(n=33)$ & 4 & 36.4 & 7 & 63.6 & \\
\hline Upper middle $(\mathrm{n}=33)$ & 11 & 52.4 & 10 & 47.6 & \\
\hline Lower $(n=191)$ & 46 & 51.1 & 54 & 48.9 & \\
\hline Poor $(\mathrm{n}=1070)$ & 410 & 55.0 & 335 & 45 & \\
\hline $\operatorname{BPL}(n=673)$ & 720 & 63.5 & 413 & 36.5 & \\
\hline Total $(n=2000)$ & 1191 & 59.5 & 809 & 40.5 & \\
\hline
\end{tabular}


"Socio-epidemiological co-relates of age at marriage: a comparative study from west Bengal".

Table IV:

Age at marriage in relation to their literacy status in two districts of West Bengal

\begin{tabular}{|c|c|c|c|c|c|}
\hline \multirow[t]{3}{*}{ District } & \multicolumn{4}{|c|}{ Age at marriage } & Test of significance \\
\hline & \multicolumn{2}{|l|}{$<18$} & \multicolumn{2}{|l|}{$>18$} & \multirow{13}{*}{$\begin{array}{l}x^{2}=135.4 \\
p=<0.0001\end{array}$} \\
\hline & No & $\%$ & No & $\%$ & \\
\hline Howrah & & & & & \\
\hline Illiterate $(\mathrm{n}=538)$ & 393 & 73.1 & 145 & 20.9 & \\
\hline Just literate $(\mathrm{n}=129)$ & 84 & 65.1 & 45 & 34.9 & \\
\hline Primary $(n=426)$ & 241 & 56.6 & 185 & 43.4 & \\
\hline Secondary\& above $(n=907)$ & 384 & 42.3 & 523 & 57.7 & \\
\hline Total $(n=2000)$ & 1102 & 55.1 & 898 & 44.5 & \\
\hline Paschim Medinipur & & & & & \\
\hline Illiterate $(\mathrm{n}=588)$ & 538 & 91.5 & 50 & 8.5 & \\
\hline Just literate $(\mathrm{n}=351)$ & 266 & 75.8 & 85 & 24.2 & \\
\hline Primary $(n=436)$ & 155 & 35.5 & 281 & 64.5 & \\
\hline Secondary $\&$ above $(n=625)$ & 134 & 21.1 & 493 & 78.9 & \\
\hline Total $(n=2000)$ & 1191 & 59.5 & 809 & 40.5 & \\
\hline
\end{tabular}

Fig-I

Comparison of age at marriage below 18 years in relation to their place of residence in two districts of West Bengal

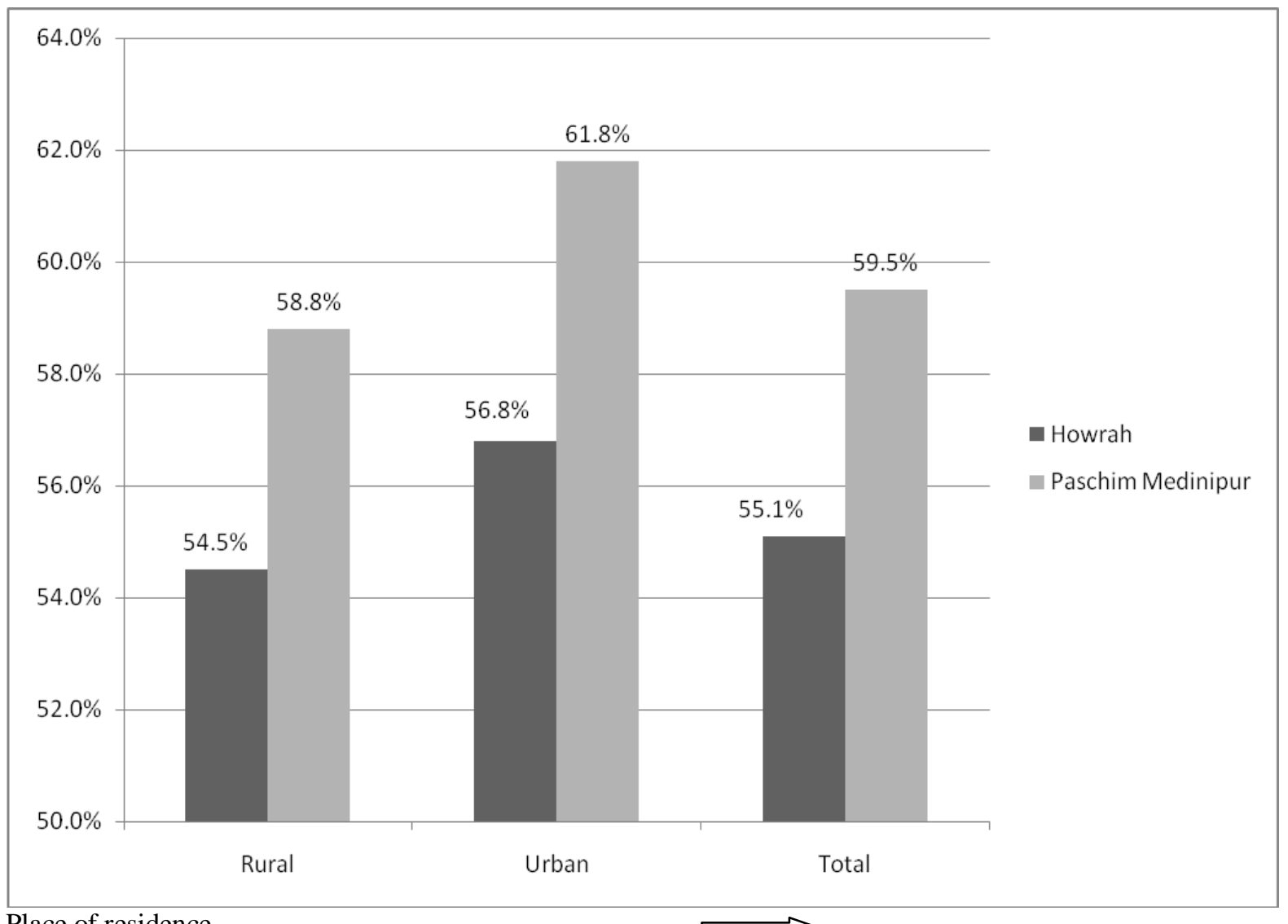

Place of residence 
"Socio-epidemiological co-relates of age at marriage: a comparative study from west Bengal".

Fig-II

Comparison of age at marriage below 18 years in relation to the literacy status of the respondents in two districts of West Bengal.

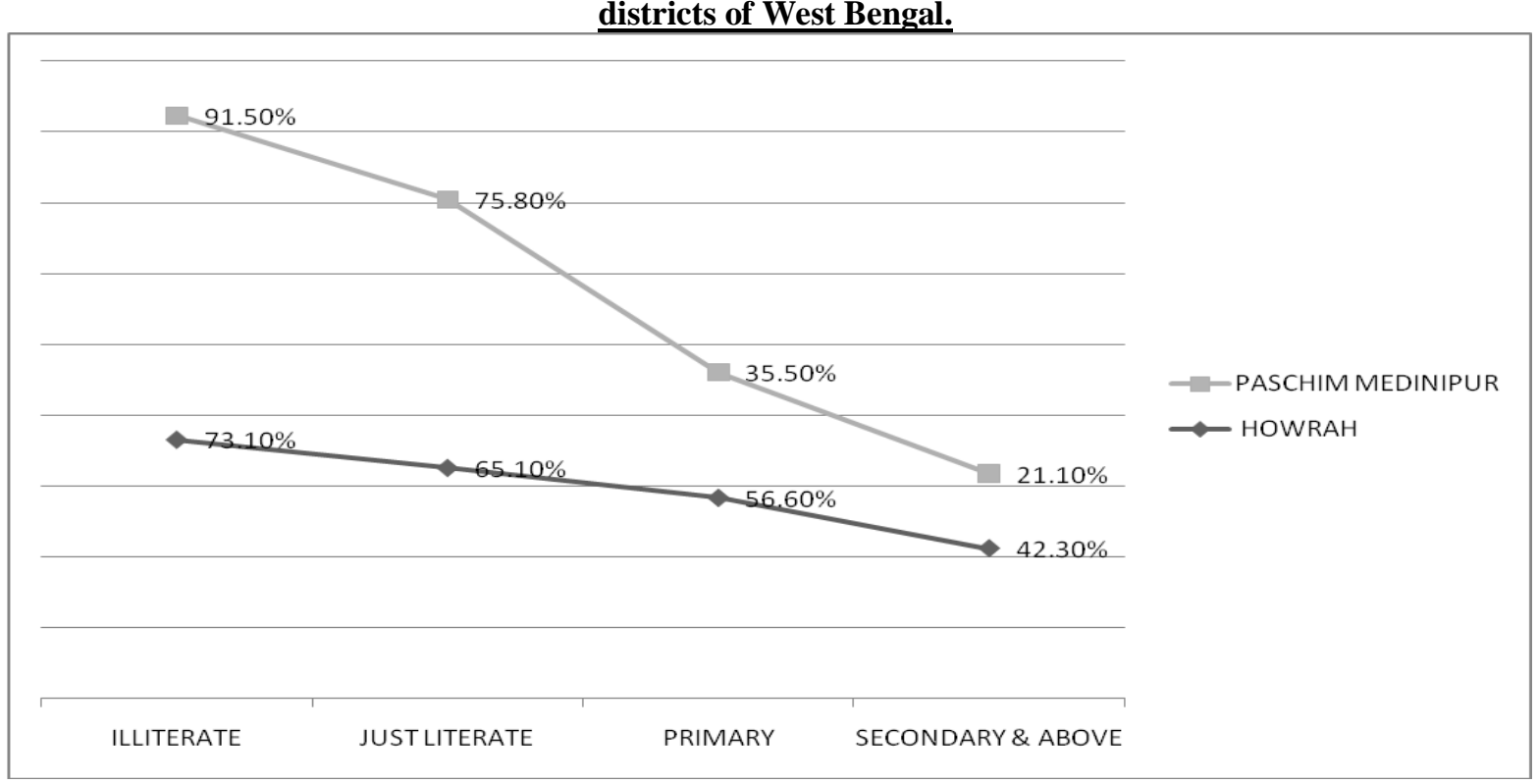

Fig-III

Comparison of occurrence in teen age pregnancy by religion between two districts of West Bengal

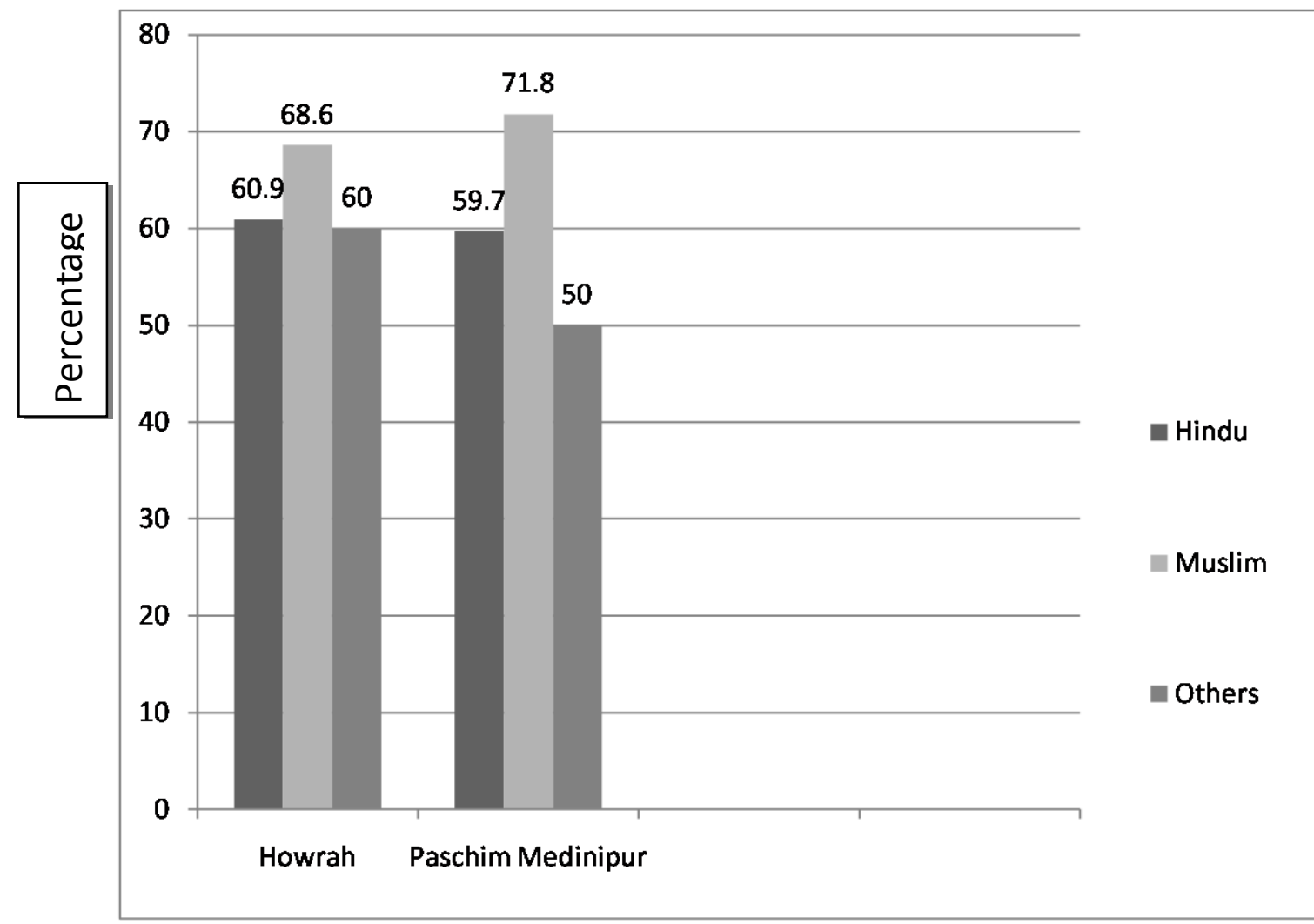

\section{District}

